\title{
Labour Formation in Small Developing States: a conceptual review
}

\author{
GODFREY BALDACCHINO, University of Malta
}

\section{Introduction}

\section{An Ecology of Smallness}

Different but corroborative research strategies suggest that there is an ecology related to country smallness (Commonwealth Secretariat, 1986, pp. 54-56; Farrugia \& Attard, 1989 , p. 15). The essential criteria seem to be a small, permanent population in a condition of self-governing isolation, resource scarcity, and a long, deep and pervasive colonial penetration. The condition may be accentuated by a number of relativities including the absence of emigration or exit outlets, poverty in combination with high material expectations, smallness and compactness of land area, and high population density.

Evidently, all territories demonstrate different quotas of each of these intervening parameters, such that the compound effects are genuinely unique in the nature and degree of impact. The 'smallness effect' may be expected to fade into insignificance as the country size increases: size, as operationalised above, may be seen to include the gross national product, land area, population size and economic/cultural self-relianceparameters which relievingly tend to exhibit high degrees of inter-correlation (Erb \& Schiavo-Campo, 1969, p. 187). The composite effect is also, ceteris paribus, expected to be more pronounced on microstates in contrast to other microterritories, because the strictures on the social field in the former are generally tighter; these microstates, especially compact island ones, contain more locally bounded experiences, resources and relationships, while always keeping in mind-especially in the context of globalisationthat there is no such thing as a closed system:

It is clear ... that a body of land entirely surrounded by water is no longer an island. (Manners, 1965, p. 183)

\section{Grounding the Metaphors}

Hence, smallness and its associated attributes carry analytic insights not generally recognised. The small developing state becomes the most likely candidate for witnessing such an ecology in action, for two main reasons. Firstly, because it exhibits high levels of the essential criteria; and it is a jurisdiction where such an ecology is demonstrably 
at work, given that social actors are also likely to accept and acknowledge this specificity.

It is both difficult and unfair to catalogue the myriad and interlocking effects of the developing smallness syndrome. Popular, illustrative general concepts have included vulnerability, scarcity, combustibility, non-viability, indivisibility and intimacy; while the metaphors of an overcrowded barracoon; a shipwrecked community; a skeleton crew; a phoney terrestrial paradise; the flotsam and jetsam of empire; forlorn peripheries always meant to be part of something larger; boats set adrift; or envious paragons of beauty and democratic consensus, are poignant and evocative. But the operationalisation of these concepts-heavily steeped in myth as they are-must perforce occur in a specific space-time configuration. And in so doing, the ensemble of features otherwise falling under the umbrella of a general rubric or metaphor is bound to be very particular, indeed unique. A distinct topography, a peculiar colonial administrative legacy, the fortunes of a cash monocrop or monoservice economy, the distance from the metropolis, the junction along trade routes and shipping lanes, the effects caused by one individual ... such and similar variables may, and do, have inordinate impact on the specifics of the small, but real, world of small states.

The ecology of smallness thus presents itself as a patterned diversity. Smallness, mediated and operationalised in real life encounters, can be conceived as one pertinent feature, along with many others, just as crucial to understand the character of the small-scale social universe.

The task at hand is not, therefore, the impossible venture of an exhaustive typology. It is rather to highlight the infection of the life of small developing states and territories by conditions which appear part and parcel of a circumstantial endowment, the ecology/geography of smallness and its accompanying economic, social, psychological, cultural and historical effects. I will limit my focus to one parameter which presents itself as peculiarly deployed in small territorial settings as described above. This is human resourcing or labour formation.

\section{Labour Formation}

The concept of labour formation acknowledges the process by which citizens are socialised into the cast of employables demanded by a particular labour market. The setting involves the education and training, formal and informal, of individuals, whereby these are imbued with the knowledge, aptitudes and attitudes which are considered relevant to them as potential labour inputs, ready and eager to join the extant factors of production. There is also typically an element of choice and screening involved, as individuals selectively direct-or get directed in - their formative paths along specific routes leading to distinct labour market segments and possibilities.

Few would contest the argument that some of the human resource problems and issues experienced by small states are similar to those of larger nations but 'writ large'. This is to say, there are more extreme, or intensified, versions of the same problems (Brock, 1987 , p. 9; Brock \& Smawfield, 1988, p. 228). These shared issues include the matching of the output of the educational system to the economy's personnel needs; promotion prospects for professional officers; the financing of educational provision.

\section{General Propositions}

Yet, this declaration of intensification is only one indicative manifestation of the peculiar 
effects of smallness on human resource deployment. It is not only a simple question of scaling down big-state precepts. One must go beyond mere calibration and posit a more holistic microstate human resourcing/labour formation syndrome. To do so effectively, it is necessary to review the literature based on general or case study research on small developing states and territories adopting a smallness-friendly, 'sociological imagination' (Wright Mills, 1959). The latter implies a methodology alert to inductive pursuit rather than anecdotal hypothetico-deduction; to what is rather than what should be.

Having undertaken such a review, and guided by the hunches derived from personal experience, a number of general propositions relating to the idiosyncrasies of labour formation in developing microstates are being put forward. The classification is neither neat nor natural, merely a convenient analytic compendium of what are ultimately interlocking and mutually impacting issues.

\section{Needed: good people}

It is likely that, without exception, every small country's development plan proclaims that the adequate provision of high-level personnel is one of its most serious constraints. It also acknowledges that, in the absence of exploitable mineral deposits and apart from God-given 'natural capital', people are the only available resource. Time and again, the crux of many problems is located in the pressing need for human resources: 'good people' (Bune, 1987, p. 85). What is the record on the production and subsequent retention of these 'good people' in microstates?

Labour Market Elasticity. One of the major difficulties facing microstate labour policy-makers is the extreme sensitivity of the economy, even to relatively small developments. Even the most modest of local projects - building a hotel or a housing estate; manning a hospital, a factory or a container terminal-is bound to strain the labour pool. The gap may be filled by expatriates or by returned migrants; and the appeal of relatively higher wages may induce occupational shifts, causing a domino effect of labour shortages in other spheres of the local economy:

A factory employing one thousand men is not large by any standard. But to set it up in a very small economy will create tensions in its restricted labour market and may even induce an immigration wave. (Butter, 1985, p. 84)

The closure of a factory which could, by itself, constitute an industry, may completely upset economic development and the employment situation (Munbodh, 1987, p. 69).

But, conversely, people with the requisite skills, already a minority, may suddenly find themselves in great demand. The higher educational system may gear itself solidly towards the preferential provision of these needed (or presumed soon to be needed) specialists. Foreign capital may set the existence of a labour skill pool as a precondition for setting up shop (and thus passing on to the state the main costs of training its workforce).

But the nature of smallness being what it is, first the market is soon saturated with specialists; then, as demographic changes set in, as the development project is terminated or as the foreign capital relocates (say, at the end of a tax holiday or of an aid package) the demand disappears as suddenly as it had emerged (Kelly, 1986; Connell, 1988, p. 56; Bacchus, 1989, p. 8):

For example, an unexpected outflow of young emigrants or a successful birth 
control campaign will quickly reduce the number of teachers needed... conversely, a baby boom will lead to a shortage (Farrugia, 1987, p. 30)

Boom and Bust Culture. The start and conclusion of a couple of major building or staffing projects thus produces a shortage and a glut of labour respectively. A seasonal industry (as could be tourism and plantation agriculture) tends towards the same cyclical, albeit more predictable, pattern. Boom and bust waves become a feature of the microstate labour scenario as the country in typical, but unadmitted, crisis-management style, invests first in one skill, then another, successively and contemporaneously. It could easily leave in its wake an assorted collection of unwanted redundant specialists. The trend, if it may be called so, is enhanced by the pressure to come up with new projects (rather than better use being made of existing ones) which meet the appeals of foreign aid/loan providers. The main concern of personnel policy thus consists first, in producing the professionals and technocrats with the skills in short or medium term demand; and, next, hopefully providing employment for them by enabling them to hop from one project to another (Knapman, 1986, p. 151; Higginson, 1987, pp. 148-149).

It is difficult to escape from this vicious circle. The limited size of both population and economy are likely to have effects on the demand for education. Because of the microstate tendency towards product specialisation, the range and level of skills required by local industries are often very restricted. This constrains the microstate's adaptability to structural changes in the world economy and to substantially impair its development potential (Caribbean Community Secretariat, 1988, p. xxvi). Diversifying the educational services by increasing the range of skills offered is only likely if there is an increased demand for trained personnel which is, however, often dependent on further economic diversification (Bacchus \& Brock, 1987, p. 5). Such a decision is often made outside the territory.

A Context of Contingency. Personnel prediction becomes unreliable in such circumstances (Fergus, 1987, p. 39; Atchoarena, 1988, p. 58). It would seem plausible to argue that, for most microstates, the decision has never really been which development strategy to choose: a free choice has never really existed. It is rather to pursue any available strategy consistently and, nevertheless, be prepared to ditch it when the situation so demands. To succeed in development is to perceive and exploit the possibilities and mitigate the obstacles as these emerge, in conformity to basic formulations of what development is understood to mean in particular contexts. There are no sacred cows, nor can there be any. Hence, there is no rigid, final, definition of development, nor of its opposite, underdevelopment. The strategy, to be relevant, must remain pragmatic, flexible and responsive to concrete strategies applied to what are understood as constantly and unpredictably changing conditions (Selwyn, 1975a, p. 20; Seers, 1983; Baldacchino, 1993).

Economic development is a problem of management-of timing, sequencing and manipulating in an unending effort to perceive or create, and in any case to exploit, a multiplicity of little openings and opportunities. (Best, 1971, p. 30)

Contrast this reality of microstate contingent and opportunist pragmatism to the Western idea of development as organic, directional, cumulative, irreversible and purposive (Moen, 1982, p. 345; Hettne, 1990, p. 80). 
For Generalist Credentials. Therefore, school programmes in small states should not encourage early specialisation, but offer pupils a good general education, as a basic foundation, in order that they may achieve the flexibility and adaptability. which they will need within jobs and in changes of employment (Bacchus, 1989, p. 13; Bray, 1992, p. 31). In addition, the instructional strategies should be of the type that develop a spirit of enquiry, experimentation and enterprise. In small states, entrepreneurial activities are likely to be on a small scale, with a higher relative dependence on individual ingenuity and innovation than may be the case in larger countries (Bacchus, 1987, pp. 61-62, 1989, p. 13).

It may also become necessary to develop a philosophy of education which subscribes to the view that it is possible and necessary to break down the separation which has existed traditionally between 'academic' and 'practical' studies. Addressing the need for such multi-purpose teaching is not easy (Bacchus, 1989, pp. 14-15): instructors need more than academic credentials to break down the pervasive dualistic pattern of 'education versus training'.

\section{Labour: an export commodity}

Labour formation is a pronounced policy priority (definitely rhetorically) for small developing states, given that people are often their only readily available and exploitable resource. This resource is at times too readily available and could constitute a demographic liability -in which case the easing of population pressure is just as important as the export of people. The latter cultivate a 'transnational corporation of kin' through whom foreign exchange could be earned and both culture-friendly consultancy and environment-friendly tourism could be tapped (Bertram \& Watters, 1985, p. 499; Connell, 1988, pp. 25-34). Labour services becomes an important export commodity (Yusuf \& Kyle Peters, 1985, p. 14):

Future emigration ... far from being a menace that threatens to deplete the islands' human resources, is counted upon as an essential element in the strategy for economic and political survival. (Hezel \& Levin, 1989, p. 42)

The provision of education as a plank in a policy of population control makes concerns over the brain drain appear to be merely academic (McKee \& Tisdell, 1990, p. 87). The smallness factor nevertheless exacerbates the opportunity cost of such measures, intensifying distortions in the sending population. It also results in the loss of single (and irreplaceable?) individuals and skills (Bennell \& Oxenham, 1983, p. 31; Barrett, 1986, p. 207; Bray \& Fergus, 1986, p. 94; Boyce, 1991, pp. 112-113; Paul et al., 1991, p. 158). Large-scale systems can afford an element of waste, of 'casting bread upon the waters'; small systems do not generally have much bread to cast (Rodhouse, 1987, p. 23). These dynamics are a result of the tight social field; hence there is much less lee-way for accommodating a mismatch between education and employment (Ward, 1975, p. 120; Brock, 1983, p. 123). Governments which anticipate and encourage migration have to ensure 'education for export': that the educational qualifications of their people are marketable in the destination countries (Fergus, 1987, p. 37; Bray, 1991a, p. 19).

Herein lies the dichotomy for educational policy-makers. Presumably, various types of skilled labour are required by nations who hope to improve their material status. By adjusting resources available for education to ensure the basic training needed to supply the skills in question, the policy-makers may unwittingly be removing the barriers 
separating their trainees from international labour markets (McKee \& Tisdell, 1990, p. 83):

Training is a ticket to the big time. (Baker, 1992a, p. 16)

\section{To Have, or Not to Have, a University?}

Labour formation is a function which is arguably the primary responsibility of the educational system. Developing microstates and territories-unlike larger communities or smaller components of larger units-feel the responsibility of such tasks weighing much more heavily on their shoulders (and purses). They are masters, for better or for worse, of their educational destiny (Brock, 1988a, p. 171).

One important policy concern is whether or not to set up local tertiary education provision or continue to derive/train specialist personnel from abroad (Bray, 1992, ch. 7).

A university must somehow always justify its funding by the state through its contribution to the intellectual, social and economic life of the nation. But nowhere is this more pressing than in small countries/territories where the university-if it existsrepresents the only institution of higher learning, and where the state is virtually the sole paymaster (Shattock, 1990, p. 1).

Smallness thus imposes a ceiling on educational provision. Expected benefits include: nation-building; a localised intellectual resource pool; avoidance of significant number of expatriates and of an intellectual brain drain; an employment area per se with multiplier effects on the local economy; opportunities for part-time and in-service courses for those in active service; a focal point for the attraction of aid from abroad. While the costs comprise: the substantial capital and recurrent financial outlay; shrinking of educational aid-such as scholarships-from abroad; the problem of attracting sufficient students willing to be educated locally to warrant scale and at the same time maintain standards; uncertainty of finding enough openings for graduates unless output is limited to low, uneconomic levels. The balance sheet of pros and cons suggests itself as idiosyncratically problematic to small states (Maxwell, 1980, pp. 345, 353-354, 362; Bray, 1991a, pp. 86-93; Peters \& Sabaroche, 1991, p. 130; Bray \& Packer, 1993, ch. 6). The notions of multifunctionality and of multifaceted institutions are appealing policy options which strive to justify the setting up locally of human, capital or organisational infrastructure in a viable manner.

\section{An Interplay of Specialist and Generalist}

Small states (and their foreign mentors) claim to have the need for much the same quality and types of skills as in larger ones. For example:

Small states have the need for much the same quality and types of skills as larger ones but can usually neither produce all these skills nor fully occupy them. (Shaw, 1982, p. 98)

The Drain of Expertise. However, while so claiming, the microstate must still tackle the implications of smallness. Firstly, there is a limited realisability of the small pool of human potential skills available: an indicator of this handicap is that almost one-quarter of the small countries in the less than five million population category still do not have a university (e.g. Lloyd \& Sundrum, 1982, pp. 28-29). Secondly, many of the talented individuals have to go abroad for further training. Once there, they may develop a 
reluctance to return to their former insular, provincial country of origin (Butter, 1985, p. 74; Diggines, 1985, p. 196; Bray, 1990, pp. 267-270; Njie \& Fye, 1991, p. 44). This is especially so if they have pursued specialist studies in areas for which the local demand for their skills is limited (Bacchus \& Brock, 1987, p. 5). Thirdly, so much local talent may be stymied and marginalised because it happens to be associated with a faction in opposition to the government of the day (Farrugia, 1987, p. 27). Fourthly, the small personnel resource-base often leads to a lack of spare capacity: staff cannot be released for further training or for initiating new projects without adversely affecting the operation of existing organisations (Bacchus \& Brock, 1987, p. 5; Bacchus, 1989, p. 8).

The composite result of all this is that the microstate can rarely come to possess all the specialisms it feels it ought to have (Shaw, 1982, p. 98). To add to the pressure, the emphasis on the high-productivity modern sector activities would not be possible with a labour formation strategy depending on large amounts of generalised labour (Shattock, 1990 , p. 7). Foreign companies continue to harp upon the absence of specialist skill shortages (Shattock, 1990, p. 12). Given the tendency towards a monocrop/monoservice economy, the range and level of such skills as may be required locally is thus even further restricted (Bacchus, 1989, p. 8). An increase in the range of skills would only be worthwhile if there is a wider economic base which is, however, seriously constrained itself by consequences of small size.

Furthermore, the microstate condition makes it most difficult for people to practise specialisms, even when and if they become available. For many specialist occupations, demand in microstates is frequently not large enough to employ even one person (Bennell \& Oxenham, 1983, p. 27; Bray, 1991a, p. 52). And the mismatch between the demands of microstate reality and the imputed expectations of professionalism results in a deformation of specialisation which many may read as a status reduction. Incumbents may prove unwilling to condone-resulting in further loss of disillusioned, skilled personnel. The pressure is strong for a broadening of one's skill profile.

Breadth versus Depth. Small countries certainly need the best; but this may sometimes be defined in terms of flexibility and breadth rather than depth (Brock, 1988b, p. 306). Expertise is too scarce to be wasted by strict adherence to job descriptions (Swartland, 1991, p. 30; Waheed Hassan, 1991, p. 99); and a critical shortage of skilled and educated labour may make it necessary to resort to multiple jobs. This generates a stress-inducing tendency to overload the talented (May \& Tupouniua, 1980, p. 106; Butter, 1985, p. 37), this being also a function of an inability to escape from a range of low-level administrative and consultative activities (Commonwealth Secretariat, 1989, p. 5; Peters \& Sabaroche, 1991, p. 123; Waheed Hassan, 1991, p. 101):

Generalists and those who have versatile specialities are often overworked because of manpower shortages and frequent vacancies. (Pillay \& Murugiah, 1991, p. 73)

Specialists may also find themselves spending most of their time travelling from one place to another, to handle both specialist and non-specialist duties (Bacchus, 1989, p. 7). Versatility in skills is a necessity in small states even for changing jobs when there is no possibility of rising higher in the same field; flexibility may be the saving grace to a blocked career path (Jock Jim \& Nuttman, 1991, p. 84; Pillay \& Murugiah, 1991, p. 66):

Generalists have better chances of promotion and specialists have to abandon 
their specialisations if they want to gain more senior posts. (Peters \& Sabaroche, 1991, p. 133)

For Flexibility. Emerging policy prescriptions include the necessity to organise technical colleges and similar educational and training institutions in a generously flexible manner. It has been suggested that one way of doing this is to operate modular courses in which components can be rearranged according to market demand (Bray, 1992, p. 31). Fine on paper, but the presentation of a set of modules to choose from is a luxury few small states can afford. The availability of courses is more likely to depend on the disposition of key members of staff or on the fortuitous presence of a willing foreign tutor.

Of course people will act flexibly, even in spite (if not because) of policy and educational histories, since that is the rule for survival. All the same, these very individuals may demand specialised training. Such a request is doubly attractive because it promotes a specific market niche for themselves as well as for their educators; and this development finds the ready blessing of foreign advisors and visiting external examiners.

Occupational Multiplicity. Hence, the interplay of specialisation and generalisation is likely to be resolved in practice with the pursuit of flexible specialisation based on occupational multiplicity, i.e. the stretching of a small number of people over a wide range of activities (Comitas, 1963, p. 41; Philpott, 1973, p. 88; Carnegie, 1982, p. 13):

The economy requires somebody to do the jobs and there are not always enough skilled people to go round. (Bray \& Fergus, 1986, p. 95)

Occupational multiplicity is a natural survival strategy assumed by labour in small-scale settings, on an individual or small group basis. The pursuit of several occupations, either simultaneously or successively, is one characteristic of areas where employment opportunities are limited; and more so where such opportunities are seasonal or precarious (Frucht, 1967, p. 296; Brookfield. 1975, p. 71; Trouillot, 1988, p. 32). These may involve both wage and non-wage labour: petty commodity production, peasant subsistence agriculture, homeworking, etc. It is a natural defence mechanism, a 'security centred survival algorithm' (Brookfield, 1975, pp. 56-57), especially if the small economy's experience is typically 'hypothermic', a collection of stop-go phenomena, with short bursts of hyperactivity being followed by decline and stagnation (Looney, 1989, p. 76). Specialisation and diversification can thus be concurrent, even lucrative, tactics in the face of uncertainty (Frucht, 1967, p. 295; Pahl, 1984, pp. 46-48; Price, 1988, p. 1).

\section{Engendering Expertise}

Going for occupational multiplicity leaves room for expertise development which carries spinoffs in the microstate environment. This is because there is an uncanny relative ease of achieving a situation of self-professed and socially acknowledged expertise: 'Many plodders make it to the top' (Kersell, 1987, p. 106), and 'In a small country ... it is easy to hit the limelight' (Bray \& Fergus, 1986, p. 94), and again 'In small countries, some employees rise higher and faster than similarly [and more?] qualified employees elsewhere (Baker, 1992a, p. 15). Such an authoritative standing is a function of a number of systemic features. 
Idiosyncratic Occupational Mobility. First, there is the relatively flat social hierarchy. There are few intermediate rungs in the ladder of social mobility, even though-and this must not be underestimated - the few (often single) competitors in the way may prove difficult to dislodge or overtake (Bacchus \& Brock, 1987, p. 5):

Their chances of moving up the occupational ladder in these small states can often prove frustrating, especially when a few young persons fill the only jobs to which they could aspire. (Bacchus, 1989, p. 8)

Individual Indulgence. Secondly, various specialisms remain vacant and unrecognised until developed and proclaimed by enterprising individuals. There are no examples to follow: in the case of new posts, job definitions and performance appraisal depend strongly on the courses charted by the officers occupying the post (Murray, 1985, p. 194; Boyce, 1991, p. 113; Peters \& Sabaroche, 1991, p. 133; Rodhouse, 1991, p. 219; Bray, 1992, p. 150). Thirdly, there is the fragility of the personnel system; with the personnel chain thinly stretched, a single break - through sickness, absence for training, or emigration-can cause disruption and considerable loss of efficiency (Shand, 1980a, p. 16; Bray, 1991a, pp. 57, 64-66; Peters \& Sabaroche, 1991, pp. 135-6; Coyne, 1992, p. 80 ). Fourthly, one can mention the execution of a policy of indigenisation. Finally, there is the discretion of job enlargement and job description lying in the hands of the individual, with superiors likely to be abroad or otherwise not actually supervising subordinates for significant stretches of time.

Screening Information. It may also be thought that, in a small nation, it would be comparatively easy to locate information-but the reverse is frequently the case. Individuals keep information to themselves as if it were personal property; colleagues are competitors for scarce resources. As a consequence, information which might even have been casually acquired is hoarded in order to secure tactical advantage. Face-to-face relations are complemented by back-to-back relations, an intriguing case of 'living apart together' (Coyne, 1992, pp. 79-80; Hoetjes, 1992, p. 131; Scruton Richardson, 1992, p. 126); or, of the left hand not knowing what the right hand is doing (Faber \& Van Vijfeijken, 1994). This is reminiscent of an otherwise cryptic pronouncement by a former microstate premier: 'We live together very well; but we don't like to live together together' (Barrow, 1964, p. 181).

These issues collectively result in the potential for 'building monuments' (Murray, 1981, p. 253).

\section{Debunking Dualist Theories}

This broad-spectrum orientation vindicates the weakness of resorting to dualist economic concepts in referring to microstates (e.g. Bennell \& Oxenham, 1983; Brock, 1983). The ideal type modern/urban/industrial versus primitive/rural/subsistence model has been found wanting even in larger economies: witness, for example, the articulation of modes of production literature (Foster-Carter, 1984). But the conceptualisation is even more difficult to hold in the case of small territories. Small distances make a mockery of the urban-rural gap, other than in dispersed archipelagic states or territories with small populations but scattered over a large land area. The activity of individuals qua producers is often one of strategic equilibrium and substitutability of these two, not so readily divisible, areas of activity, at the individual or collective level. Available 
evidence and policy proposals point towards a merging via, for instance, multi-functional structures, part-time staffing and regional resource sharing (Murray, 1981; Bennell \& Oxenham, 1983, p. 29; Farrugia \& Attard, 1989, pp. 69-71; Bray, 1992, pp. 145-147).

\section{Educational Dependency}

Enhanced Cultural Penetration. The microterritory scenario is generally a cosmopoli$\tan$ one. It thus presents a higher level of formal educational achievement (Bray \& Fergus, 1986, p. 100). Again, this appears to be enhanced by smallness, which accentuates Western cultural penetration via the colonial presence (Dommen, 1980, p. 942; Bray \& Fergus, 1986, p. 94; Bray \& Packer, 1993, p. 210). Former colonial regimes introduced a system of Western schooling, both in the interests of cooptative acculturation, as well as to recruit literate workers into the lower echelons of the civil service. Educational resources and their associated high prestige, were thus oriented towards salaried, often public sector, employment (Bennell \& Oxenham, 1983, pp. 18-19; Thomas \& Postlethwaite, 1984; McKee \& Tisde1l, 1990, pp. 88-89). Such an orientation tends to persist because the public sector remains a popular, stable and available field of employment (Bacchus, 1989, p. 6). The heavy dependence on trade, tourism and other foreign flows continues to exercise pressure on a metropolitan orientation in the educational system via, say, the learning of foreign languages, perhaps to the detriment of local ones (Bray, 1991a, p. 19). Microstate governments have criticised the alien educational system they inherited with political independence: 'Like Ruth amidst the alien corn' (Eric Williams, 1946, quoted in Maxwell, 1980, p. 365). Furthermore, microstate educators are themselves invariably trained abroad in the metropolis and usually return home imbued with the theory and content of courses which they generally seek to duplicate or reproduce, laced with the glamour accorded to international credentials. This tendency is even more significant when microstate academics are themselves expatriates (Higginson, 1987, pp. 144-145; Thaman, 1987, p. 58; Njie \& Fye, 1991, p. 44; Pillay \& Murugiah, 1991, p. 68; Bray, 1992, pp. 51-52).

Academic Inertia. It is conjectural whether microstates can benefit in the same way, and to the same extent, from the educational standards, orientations and course curricula of a manifestly different type of (also large scale) society. These are powerful agents of inertia. There are often only token attempts in microstates to usurp cultural dependency, developing locally relevant standards of education oriented towards growth and development, which specifically recognise in the process local conditions, influences and problems-particularly those emanating from the condition of small scale (Hardman, 1984 , p. 151; Brock \& Smawfield, 1988, p. 236). The metropole's academic model remains ingrained as the most desirable form of education, albeit the least relevant (Bennell \& Oxenham, 1983, p. 22; Brock, 1983, p. 127, 1988a, p. 177; Brock \& Parker, 1985 , p. 53). One indication of this is the enthusiasm with which microstate governments take up foreign consultants (Bray, 1991, p. 86; Fergus \& Thomas, 1991, pp. 171-172), foreign textbooks (Bray, 1991b, p. 7) and foreign examinations (Fergus, 1987, p. 43; Miller, 1987, p. 135; Brock \& Smawfield, 1988, p. 229; Bray, 1991b, p. 8; Fergus \& Thomas, 1991, pp. 170-1; Jock Jim \& Nuttman, 1991, p. 82).

\section{The Price of Aid}

At the same time, the microstate territory is under duress to project itself as an attractive 
site for foreign largesse and to provide a vehicle of international accreditation and prestige to its upwardly and globally mobile, often elite, citizens (Fergus, 1987, p. 43; Brock \& Smawfield, 1988, p. 235; Bray, 1990, p. 270; McKee \& Tisdell, 1990, p. 87; Jock Jim \& Nuttman, 1991, p. 87). The operation of schooling as a vehicle for emigration to professional occupations abroad fitted in well with the highly selective and academic model of schooling bequeathed to small states as part of their colonial legacy. But the notion of 'education for emigration' is now a lower priority and its adjustment towards localisation is a key challenge (Brock, 1987, p. 14).

Dealing with Donors. Insufficient high-level, 'professional' expertise would jeopardise the credibility and external recognition of the intellectual standing of a microstate's citizenry and workforce in the eyes of the international community (Bennell \& Oxenham, 1983, p. 30; Swartland, 1991, p. 30). One priority here is to relate with a donor in an expeditious and effective manner, thus enhancing the microstate's absorptive capacity and the ability to effectively utilise financial or technical support from abroad which might be made available to it (Lestrade, 1987, p. 81). This is generally substantial and would otherwise constitute a considerable loss (De Vreis, 1975; Bray \& Fergus, 1986, p. 93; Knapman, 1986; Goodridge \& Peters, 1987; Bray, 1990, p. 269; Pillay.\& Murugiah, 1991, pp. 67-68; Bray \& Packer, 1993, ch. 10). All the same, the demands placed on the microstate educational system in regard to overseas linkages (such as the management of overseas aid, attending to requests for information, project formulation for foreign funding, membership of international and regional institutions, trips abroad, the management of overseas scholarships) are just as onerous (Commonwealth Secretariat, 1989, p. 5; Boyce, 1991, p. 118; Bray, 1991a, p. 20; Fergus \& Thomas, 1991, p. 179; Njie \& Fye, 1991, p. 46). The amount of time spent implementing foreign projects, as opposed to routine and locally funded activity, may not be commensurate to their importance (Paul et al., 1991, p. 157). It is tempting to accept aid just because it is offered. But aid may be costly: it may prove necessary to refuse aid that is not in keeping with development plans or goals (Beiabure Bakeea, 1991, pp. 257-258; Fergus \& Thomas, 1991, pp. 176-178; Peters \& Sabaroche, 1991, p. 134).

An Identity Conflict. To a large extent, the same educational process which opens minds to a larger world also arouses discontent with the limitations of small, especially island, life (Kiribati Development Plan, 1979-1982, quoted in Bennell \& Oxenham, 1983 , p. 21). Many small states are in search of an acceptable balance between the development of a local education system and some measure of dependence on financial support and services provided by foreign sponsors. This tension falls within a general identity conflict between local/indigenous (but often itself hybrid and manufactured) and metropolitan/foreign orientations (Harrigan, 1972; Fergus, 1987, pp. 37-38; Brock, 1988 b, p. 307 ; Bray, 1990 , p. 267). The old pattern of education, however, generally holds sway, with its irrelevant élitism, selectivity and generation of unrealistic expectations (Bennell \& Oxenham, 1983, p. 23).

\section{Personal Imprints}

Finally, one can take cognisance of the practice in many small states of how organisation charts are constantly changed, warped, or outrightly flouted to accommodate new individuals and to fit changing patterns of human resource availability (Beiabure Bakeea, 1991, p. 262; Bray, 1991b, p. 11, 1992, p. 150; Baker, 1992a, p. 15). This is also a 
function of how 'natural monopoly' engenders personalities having a strong impact on the operation of organisations (Swartland, 1991, p. 31; Wettenhall \& Thynne, 1994). There is often a transparent, acute personalisation of institutional goings on:

Because of the critical shortage of manpower, jobs are often created to suit available persons. Familiarity and experience count most in appointment to senior positions. ... Personnel appraisal becomes a subjective and invariably a process of testing of loyalties and performance. (Waheed Hassan, 1991, p. 100)

and

Sometimes, functions are assigned to institutions in the view of the abilities or experience of their incumbent authorities, and therefore change whenever these persons change positions. (Jacome, 1992, p. 241)

Witness also the resort to recruitment, promotion or preferential treatment on the basis of particularistic criteria-or, the formalistic, overdone resort to universalistic criteria to suggest fair and just treatment (Bray, 1992, p. 152). But could these measures nevertheless be used to justify and condone the selection of a favourite?

\section{Conclusion - the elusive capacity for relevance}

Small developing states may share unique social, political and administrative characteristics that are as potentially conducive for development as would be the adoption of externally developed models of modernisation. Unfortunately, the current research on the small developing state ... has not provided the kind of comparative research that would be useful for discovering these shared developmental possibilities. (Schahczenski, 1990, p. 79)

With the cluster of features identified above, developing microstates appear thus as candidates which require labour resourcing policies crucially; but, concurrently, their policy makers are likely to misconstrue what such policies should in practice be all about. The smaller the state, the less likely it appears to develop the economic and technical (and, one may hazard to add, the psychological) capacity for producing new, more locally relevant, curriculum materials, inter alia, at any level (Brock, 1988b, p. 306). Blinded by cosmopolitanism, the temptation to (and sheer pride in) copying model, larger states, along with the imperative to appear internationally attractive, the developing microstate's human resourcing/labour formation programme may be significantly alienated from its home environment. In addition, failure when it comes (and come it must sometimes) is quickly highlighted, made public and condemned in small systems. This fuels systemic inertia and 'playing safe': better to do well what is accepted than risk poor performance of new, untried methods and techniques (Munbodh, 1987, p. 72; Rodhouse, 1987, pp. 23-24). Personnel planning adheres to the specialisations and specifications of the larger societies and seems unwilling - or unable? - to accept the implications of smallness (Bennell \& Oxenham, 1983, p. 24). Even in the educational institutions of small states, the amount of research which examines small states as small states as opposed to states which merely happen to be small has so far been disappointing (e.g. Bray \& Packer, 1993).

This paper is meant to serve as a synoptic conceptual coverage of issues which are brought to bear on the specificity of personnel planning and human resourcing in small 
developing states. Its unfolding implicit agenda is a plea for a departure from prescriptive, 'common sense' arguments and an appreciation of a reflexive and home-grown 'good sense'. It is inductive research which brings to light episodes which provide a rich corpus of behavioural data, evidence of the nuanced human resource practices of small jurisdictions. These vignettes exemplify the strategies entered into by people to best handle, as they see fit, relations with nature and with others, addressing smallness and its effects naturally in the process.

The plight of many small, especially island, developing states has been highlighted of late with the mounting concern for sustainable development. These territories are likely to prove amongst the first victims of global warming and sea level rise (Bennet \& Towle, 1981; Bray, 1991a, p. 16). In much the same way, this article expounds on a concern for a different, but just as pertinent, blend of sustainability, one based on the strength of a home-grown, street wisdom governing small state affairs. Human resourcing is but one example of this.

Correspondence: Dr Godfrey Baldacchino, Workers' Participation Development Centre, University of Malta; Msida, Malta, MSD 06.

\section{REFERENCES}

AtchoAREnA, D. (1988) La planification de l'education et de la formation en milieu micro-insulaire, Formation et Developpement, 8, pp. 55-62.

BACCHUS, M.K. (1987) The provision of post-secondary education in small nation states, in: M. K. BACCHUS \& C. BrocK (Eds) (1987) op. cit., pp. 61-67.

Bacchus, M.K. (1989) Educational Needs of Small Nation States with Special Reference to Education at Post-Secondary States (Brunei Darussalam, Universiti Brunei Darussalam and World Bank).

Bacchus, M.K. \& Brock, C. (1987) Editorial introduction, in: M. K. BAcchus \& C. Brock (Eds) op. cit., pp. $1-7$.

BACchus, M.K. \& Brock, C. (Eds) (1987) The Challenge of Scale: educational development in the small states of the Commonwealth (London, Commonwealth Secretariat).

BAKER, R. (1992a) Scale and Administrative Performance: the governance of small states and microstates, in: R. BAKER (Ed.) op. cit., pp. 5-25.

BAKER, R. (Ed.) (1992b) Public Administration in Small and Island States (West Hartford, CT, Kumarian Press).

BaldaCchino, G. (1993) Bursting the bubble: the pseudo-development strategies of microstates, Development and Change, 24, pp. 29-51.

BARRETT, I. (1986) Administrative problems of small island states with particular reference to the states of the Eastern Caribbean, Social \& Economic Studies, 35, pp. 199-213.

Barrow, E. (1964) A role for Canada in the West Indies, International Journal, 19, pp. 172-187.

Beiabure BaKeEA, M. (1991) Kiribati, in: M. Bray (Ed.) op. cit., pp. 247-264.

BenNell, P. \& OXENHAM, J. (1983) Skills and qualifications for small island states, Labour and Society, 8, pp. $13-38$.

BENNET, J. \& TowLE, E.L. (1981) Energy/environmental management: a broad perspective for the islands of the Caribbean, Caribbean Educational Bulletin, 8, pp. 13-33.

Bertram, I.G. \& Watters, R.F. (1985) The MIRAB economy in South Pacific microstates, Pacific Viewpoint, 26, pp. 497-519.

Best, L. (1971) Size and survival, in: N. GiRvan \& O. JefFerson (Eds) Readings in the Political Economy of the Caribbean, pp. 29-34 (Jamaica, New World Associates).

Boyce, R. (1991) Barbados, in: M. Bray (Ed.) op. cit., pp. 106-122.

Bray, M. (1990) Provision of higher education in small states: demands, constraints and strategies, Higher Education Quarterly, 44, pp. 264-281.

BRAY, M. (Ed.) (1991 a) Ministries of Education in Small States: case studies of organisation and management (London, Commonwealth Secretariat). 
Bray, M. with Charles, H., Farrugla, C.J., Packer, S. \& Swartland, J. (1991b) Making Small Practical: the organisation and management of ministries of education in small states (London, Commonwealth Secretariat).

BRAY; M. (1992) Educational Planning in Small Countries (Paris, UNESCO).

Bray, M. \& FERGUS, H.E. (1986) The implications of size for educational development in small countries: Montserrat, a Caribbean case study, Compare, 16, pp. 91-102.

Bray, M. \& PACKER, S. (1993) Education in Small States: concepts, challenges and strategies (Oxford, Pergamon Press).

BRock, C. (1983) Education, environment and economy in small Commonwealth countries, in: J. K. P. WATSON (Ed.) Youth, Education and Employment, pp. 122-145 (London, Croom Helm).

BRock, C. (1987) The educational context, in: K. BACCHus \& C. Brock (Eds) op. cit., pp. 8-18.

Brock, C. (1988a) Beyond the fringe? Small states and the provision of education, Comparative Education, 24, pp. 167-179.

Brock, C. (1988b) Education and national scale; the world of small states, Prospects, 18, pp. 303-314.

Brock, C. \& PARKer, R. (1985) School and community in situations of close proximity: the question of small states, in: K. M. Lillis (Ed.) School and Community in Less Developed Areas, pp. 42-56 (London, Croom Helm).

Brock, C. \& SMAwField, D. (1988) Education and development: the issue of small states, Educational Review, 40, pp. 227-239.

BRoOKFIELD, H.C. (1975) Multum in parvo: questions about diversity and diversification in small developing countries, in: P. SELWYN (Ed.) op. cit., pp. 54-76.

Bune, P. (1987) Vulnerability of small island states: the case of the South Pacific region and Fiji, Courier, No. 104 , pp. $85-87$.

Butter, A.J. (1985) An Introduction to Mini-Economics (Amsterdam, B. R. Gruner).

CARIBBEAn COMmunity SECRETARIAT (1988) Caribbean Development to the Year 2000: challenges, prospects and policies (London and Guyana, Commonwealth Secretariat and Caribbean Community Secretariat).

Carnegie, C.V. (1982) Strategic flexibility in the West Indies; a social psychology of Caribbean migration, Caribbean Review, 11, pp. 10-13, 54.

Comitas, L. (1963) Occupational multiplicity in rural Jamaica, Proceedings of the 1963 Annual Spring Meeting of the American Ethnological Society, Seattle.

COMmONWEALTH SECRETARIAT (1986) Educational Development: the small states of the Commonwealth, Report of a Pan-Commonwealth Experts Meeting-Mauritius 1985 (London, Commonwealth Secretariat).

Commonwealth Secretariat (1989) A Pan-Commonwealth Meeting on the Organisation and Management of Ministries of Education in Small States, Summary of Conclusions and Outcomes (London, Education Programme, Commonwealth Secretariat).

Connell, J. (1988) Sovreignty and Survival: island microstates in the Third World, Research Monograph No. 3 (Sydney, Department of Geography, University of Sydney).

COYNE, G. (1992) The impact of culture on small scale administration: the case of Solomon Islands, in: R. BAKER (Ed.) op. cit., pp. 71-83.

DE VRIES, B.A. (1975) Development aid to small countries, irt: P. SELwYN (Ed.) op. cit., pp. 164-184.

DrgGines, C.E. (1985) The problems of small states, Round Table, 74, pp. 191-205.

DommEn, E.C. (1980) Some distinguishing characteristics of island states, World Development, 8, pp. 931-944.

Dommen, E.C. \& Hein, P.L. (Eds) (1985) States, Microstates and Islands (London, Croom Helm).

ERB, G.F. \& SCHIAvo-CAmpo, S. (1969) Export stability, level of development and economic size of less developed countries, Bulletin of Oxford University Institute of Economics and Statistics, 31, pp. 263-283.

Faber, D.C. \& von Vufeuken, T.M. (1994) Does the right hand know what the left hand is doing? The management of sectoral linkages in the eastern Caribbean, Asian Joumal of Public Administration, 16, pp. 87-108.

Farrugia, C.J. (1987) The professional development of educational personnel in small states, in: M.K. BACCHUS \& C. BROCK (Eds) op. cit., pp. 25-35.

Farrugia, C.J. \& ATTARD, P.A. (1989) The Multifunctional Administrator (London, Commonwealth Secretariat).

Fergus, H.E. (1987) The development of curriculum and materials in small states: a Caribbean view, in: K. BACCHus \& C. Brock (Eds) op. cit., pp. 36-49.

Fergus, H.E. \& Thomas, A.L. (1991) Montserrat, in: M. Bray (Ed.) op. cit., pp. 163-182.

Foster-CARTER, A. (1984) The modes of production controversy, New Left Review, No. 107, pp. 47-77.

FRUCHT, R. (1967) A Caribbean social type: neither peasant nor proletarian, Social and Economic Studies, 16, pp. 295-300.

Goodridge, R. \& Peters, B. (1987) Aid for education, in: K. Bacchus \& C. Brock (Eds) op. cit., pp. 151-157. 
HARDMAN, D.J. (1984) Public financial administration of microstates: the South Pacific Forum, Public Administration and Development, 4, pp. 141-154.

HARRIGAN, N.E. (1972) Higher education in the micro-state: a theory of Raran society, unpublished PhD Thesis, University of Pittsburgh, School of Education.

HetTnE, B. (1990) Development Theory and the Three Worlds (Essex, UK, Longman).

Hezel, R. \& LEVIN, M. (1989) Micronesian emigration: beyond the brain drain', in: J. ConNell (Ed.) Migration and Development in the South Pacific, Research Monograph No. 24, pp. 42-60 (Canberra, Australian National University, National Centre for Development Studies).

HrgGinson, P. (1987) Factors affecting the programming of multilateral assistance to education in the Pacific island states: a view from UNESCO/SOPAC, in: K. BACCHUS \& C. BROCK (Eds) op. cit., pp. 140-150.

HoETJES, B.J.S. (1992) The Dutch connection in the Caribbean: six islands living apart together, in: R. BAKER (Ed.) op. cit., pp. 131-143.

JACOME, J.M. (1992) The Commonwealth Caribbean small island states and the Caribbean Centre for Development Administration: a management development institution, in: R. BAKER (Ed.) op. cit., pp. 233-251.

JoCK JiM, L. \& NutTMan, C.J. (1991) Brunei Darussalam, in: M. Bray (Ed.) op. cit., pp. 74-89.

KELLY, D. (1986) St. Lucia's female electronics factory workers: key components in an export-oriented industrialisation strategy, World Development, 14 , pp. 823-838.

Kersell, J.E. (1987) Government administration in a very small microstate: developing the Turks and Caicos Islands, Public Administration and Development, 8, pp. 95-107.

KNAPMAN, B. (1986) Aid and the dependent development of Pacific island states, Journal of Pacific History, 21 , pp. $139-152$.

LESTRADE, S. (1987) Economic issues affecting the development of small island states-the case of the Caribbean, Courier, No. 104, pp. 78-84.

Lloyd, P.J. \& SUNDRum, R.M. (1982) Characteristics of small economies, in: B. JALAN (Ed.) Problems and Policies in Small Economies, pp. 17-38 (London, Croom Helm).

LOONEY, R.E. (1989) Macroeconomic consequences of the size of third world nations: with special reference to the Caribbean, World Development, 17, pp. 69-83.

MANNERS, R.A. (1965) Remittances and the unit of analysis in anthropological research, South Western Journal of Anthropology, 21, pp. 179-195.

MAY, R.T. \& TUPOUniuA, S. (1980) The politics of small island states, in: R.T. SHAND (Ed.) op. cit., pp. $419-437$.

Maxwell, I.C.M. (1980) Universities in Partnership: the Inter-University Council and the growth of higher education in developing countries: 1946-1970 (Edinburgh, Scottish Academic Press).

MCKeE, D.L. \& Tisdell, C.A. (1990) Developmental Issues in Small Island Economies (New York, Praeger).

MiLler, E. (1987) Caribbean regionalism, education and marginality, in: K. BACCHus \& C. Brock (Eds) op. cit., pp. 127-139.

Moen, A. (1982) Curaçao 1969: crisis and change, in: S. Craig (Ed.) Contemporary Caribbean: a sociological reader, Vol. 2, pp. 337-364 (Maracas, Trinidad \& Tobago, The College Press).

MunbodH, S. (1987) The technical education needs of the small states of the Commonwealth, in: K. BACCHUS \& C. BRock (Eds) op. cit., pp. 68-79.

Murray, D. (1981) Microstates: public administration for the small and beautiful, Public Administration and Development, 1, pp. 245-256.

Murray, D. (1985) Public administration in the microstates of the Pacific, in: E.C. DOMMEN \& P.L. HEIN (Eds) op. cit., pp. 185-203.

NuE, G. \& Fye, S. (1991) The Gambia, in: M. Bray (Ed.) op. cit., pp. 35-50.

PAHL, R.E. (1984) Divisions of Labour (Oxford, Blackwell).

Paul, U.M., Bernard, M., Dash, R. \& Hamllton, E. (1991) Guyana, in: M. Bray (Ed.) op. cit., pp. 139-162.

Peters, M.E. \& Sabaroche, H.F. (1991) Dominica, in: M. Bray (Ed.) op. cit., pp. 123-138.

PhiLPotT, S.B. (1973) West Indian migration: the Montserrat case, London School of Economics, Monographs on Social Anthropology, No. 47 (London, Athlone Press).

Pillay, P. \& Murugiah, A. (1991) Seychelles, in: M. Bray (Ed.) op. cit., pp. 51-73.

PrICE, N. (1988) Behind the Planter's Back: lower class responses to marginality in Bequia Island, St Vincent (London, Macmillan).

Rodhouse, J. (1987) Problems of policy and development, in: K. BACCHus \& C. Brock (Eds) op. cit., pp. 19-24.

Rodhouse, J. (1991) Jersey, in: M. BRAY (Ed.) op. cit., pp. 209-227. 
SCHAHCZENSKI, J.J. (1990) Development administration in the small developing state, Public Administration and Development, 10 , pp. 69-80.

SCRUTON RICHARDSON, S. (1992) The continuing role of non-nationals in the administration of the United Arab Emirates: the dilemma of a small sovereign state, in: R. BAKER (Ed.) op. cit., pp. 116-130.

SeERs, D. (1983) The Political Economy of Nationalism (Oxford, Oxford University Press).

SELWYN, P. (1975a) Room for manoeuvre?, in: P. SELWYN (Ed.) op. cit., pp. 8-24.

SELwyn, P. (Ed.) (1975) Development Policy in Small Countries (London, Croom Helm in association with the Institute of Development Studies, Sussex).

SHAND, R.T. (1980a) Island smallness: some definitions and implications, in: R. T. SHAND (Ed.) op. cit., pp. $1-16$.

SHand, R.T. (Ed.) (1980b) The Island States of the Pacific and Indian Oceans: anatomy of development, Monograph No. 23 (Canberra, Development Studies Centre, Australian National University).

Shatтock, M. (1990) A Strategic Plan for the University of Malta (Coventry, UK, University of Warwick, Warwick Research Institute).

SHAw, B. (1982) Smallness, islandness, remoteness and resources: an analytical framework, Regional Development Dialogue, Special Issue, pp. 95-109.

SwartLand, J. (1991) Botswana, in: M. BRAY (Ed.) op. cit., pp. 21-34.

Thaman, J. (1987) Curriculum development in Pacific island countries with special reference to Tonga, in: $\mathrm{K}$. BACCHUS \& C. BRocK (Eds) op. cit., pp. 50-60.

Thomas, R.M. \& Postlethwatte, T.N. (1984) Schooling in the Pacific Islands: colonies in transition (Oxford, Pergamon).

Troulllot, M.R. (1988) Peasants and Capital: Dominica in the world economy (London, Johns Hopkins University Press).

Waheed Hassan, M. (1991) Maldives, in: M. Bray (Ed.) op. cit., pp. 90-105.

WARD, M. (1975) Dependent development-problems of economic planning in small developing countries, in: P. SELWyn (Ed.) op. cit., pp. 115-133.

WetTenhalL, R. \& ThYNnE, I. (1994) Machinery of government innovation in micro-states: the case of Nauru, Niue \& Norfolk Island, Asian Joumal of Public Administration, 16, pp. 60-86.

Wright Mills, C. (1959) The Sociological Imagination (New York, Oxford University Press).

YusUf, S. \& KYLE PETERS, R. (1985) Western Samoa: the experience of slow growth and resource imbalance, World Bank Staff Working Papers No. 754 (Washington, DC, The World Bank). 